Portland State University

PDXScholar

6-16-2021

\title{
Suppressing Our Vote: How Vote-by-Mail Affects Latino Voter Turnout
}

\author{
M. Karen Casas-Gonzalez \\ Portland State University
}

Follow this and additional works at: https://pdxscholar.library.pdx.edu/honorstheses

Part of the Political Science Commons

Let us know how access to this document benefits you.

\section{Recommended Citation}

Casas-Gonzalez, M. Karen, "Suppressing Our Vote: How Vote-by-Mail Affects Latino Voter Turnout" (2021). University Honors Theses. Paper 1102.

https://doi.org/10.15760/honors.1129

This Thesis is brought to you for free and open access. It has been accepted for inclusion in University Honors Theses by an authorized administrator of PDXScholar. Please contact us if we can make this document more accessible: pdxscholar@pdx.edu. 
Suppressing Our Vote: How Vote-by-Mail Affects Latino Voter Turnout

By:

M. Karen Casas-Gonzalez

An undergraduate honors thesis submitted in the partial fulfillment of the requirements for the degree of

Bachelor of Arts

in

University Honors

and

Political Science

Thesis advisor:

Richard Clucas

Portland State University 


\begin{abstract}
Voter suppression has damaged our democracy and will continue to do so until citizens are given accessibility to voting through various means such as vote-by-mail. Voter suppression has disproportionately and historically affected people of color. The basis of this thesis is to highlight the effects of voter suppression in the Latino community, but more importantly to look at the possible benefits of vote-by-mail as a new political reform to increase voter turnout. The 2020 election was a unique and historical moment for further research on this topic due to the COVID-19 pandemic. Previously, only a few states had vote-by-mail. However, due to the circumstances of the pandemic, numerous states allowed it. The purpose of this thesis is to compare and contrast how vote-by-mail affects voter turnout by focusing on states that adopted the system in the 2020 election with states who already had it implemented. The overall goal is to understand if vote-by-mail has a positive or negative effect on our democracy and how this system of political reform can help increase voter turnout.
\end{abstract}




\section{Table of Contents}

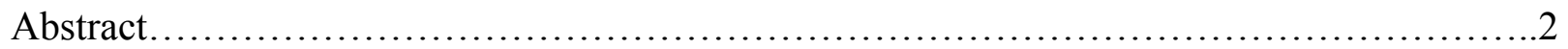

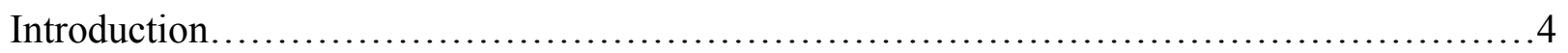

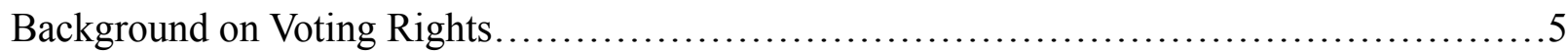

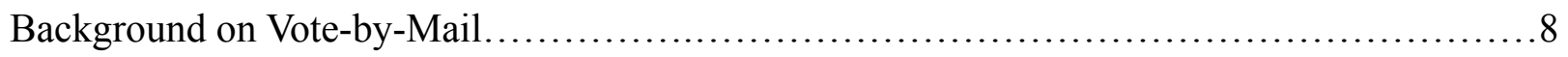

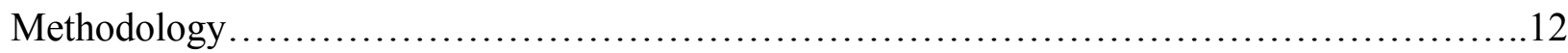

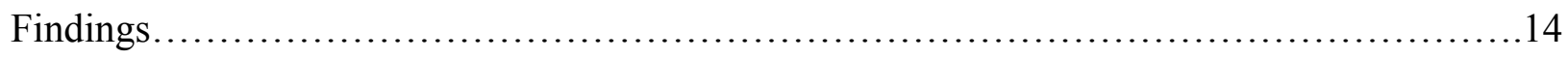

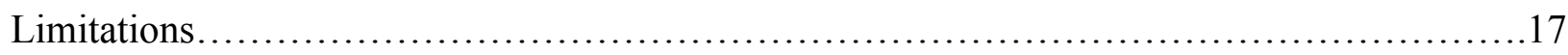

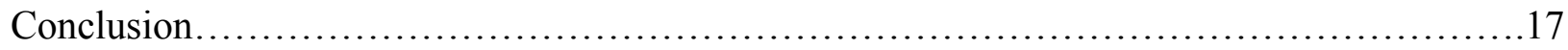

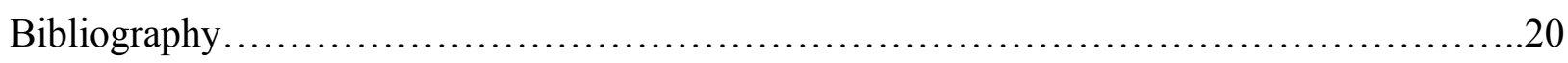




\title{
Introduction
}

\author{
"Your vote is precious, almost sacred. It is the most \\ powerful non-violent tool we have in a democracy." \\ -Rep. John Lewis
}

The unfortunate truth is that people of color, especially Latinos have some of the lowest voter turnout and political participation. The Latino community has increased in numbers yet their voter turnout rate has failed to increase over the past few years. According to data from the 2016 election, Latino voter turnout has gone down about $2.3 \%$ since the 2008 election (Varela, 2017). Although the Latino community is growing stronger in numbers in the United States, that truth is not reflected in political participation, which only hurts the community.

The fight for the right to vote is a process that has taken people of color years to achieve. Vote-by-mail can be a political reform system that can change and help close the gap between voter turnout. Unfortunately, before the 2020 election, only five states had all-mail in ballots. Those states were Colorado, Hawaii, Oregon, Utah, and Washington. It is important to note that in the 2020 election, of the top six states with the highest voter turnout, three of them were states that had implemented vote-by-mail for a number of years (Berkman, 2021).

The overall goal is to see how much impact vote-by-mail has on Latino voter turnout, and more importantly what this can mean for our democracy. This topic is important because it is not just about voting for the president, it is about voting for someone who will benefit and work in the best interest of the community. Through accessible voting, we as citizens are able to support and encourage legislation that can have long-lasting effects for future generations. More importantly, legislation that can change and help people now in the present moment. This is not just about voting, it is about proper representation and having the voices of all eligible voters being heard. 


\section{Background on Voting Rights}

Historically, the idea that one person equals one vote has been far from the truth. The right of citizens of the United States to vote shall not be denied or abridged by the United States or by any State on account of race, color, or previous condition of servitude (U.S. Const. Amend. $\mathrm{XV})$. Although this was written in the constitution in 1870 that everyone should have the right to vote "Mostly white Anglo-Saxon Protestant males, who own property and are older than 21, are the only group allowed to vote" (Kennedy, 2021). It was not until many years later that more Americans were given the right to vote.

Even then, it took numerous years of fighting for different groups to vote. For example, it was until 1920 that women were given the right to vote, but even then southern states created restrictions for minority women. The same was for minorities, especially black people who were given a series of literacy tests and poll taxes in order to make voting more difficult. It was not later until the passage of the Voting Rights Act of 1965 was passed, which banned literacy tests and enforced the 15th Amendment at the federal level that more black citizens were able to vote. This led to wides-spread voter activity, "Virginia increased its voter registration of Black voters and almost doubled in three and a half years" (Wesley, 1972). In 1975, an amendment was added to the Voting Rights Act requiring districts with significant numbers of non-English-speaking voters to provide instructions and assistance with registering and voting. Latinos and other language minorities became primary beneficiaries of the 1975 VRA (Fraga 2017, 8). Years later, in 1993 , registration became simpler through the motor voter law which allowed voters to register at motor vehicle departments (Kennedy, 2021). The motor voter law made registering simpler which in turn helped increase voter registration.

An equal system where one person represents one vote has been distorted in the American political system since its foundation. According to Barbara Combs "The aim of this 
modern form of opposition is to repel black and brown bodies and send them back to their place - a place always distinct from and most often subservient to whites. Systematic voter suppression is one of the most successful of those new opposition techniques" (Combs, 2016). Combs further analyzes how things such as population shifts should be reflected in voter turnout, yet they aren not. The article uses historical tactics such as Jim Crow, which are linked to voter suppression to this day. More specifically, the book by Chandler Davidson "outlines the tactics states and local governments used to evade the full impact of black and Latino voting rights after 1965 and how those groups fought back through the courts" (Mills, 1990). Tactics such as voter disenfranchisement which are prevalent to this day.

Similarly, Benjamin Highton touches on the low Latino voter turnout and its many causes. Highton touches on one of the problems when reporting Latino voter turnout, which is not considering citizenship, "Using the latter increases the estimate of 1996 Latino turnout 17.4\% points to 44.3\%" (Highton, 2016). Like Combs, Highton also brings forward the shift in the Latino population and the fact that the Latino community is the largest minority in the United States, meaning they hold significant political power. Yet, there seems to be a lack of research and pattern data collection on Latino voter turnout in presidential elections.

Although it has been many years since the Benjamin Highton paper, an article by Julio Varela showed little to no increase in Latino voter turnout. Varela analyzes data from presidential elections and notes that "The voting rate for Latinos in 2016 was $47.6 \%$ and $48 \%$ in 2012. In 2008, the voting rate for Latinos was $49.9 \% \ldots$ Despite the decrease, the voter share for Latinos increased to $9.2 \%$ in 2016 , compared to $8.4 \%$ in 2012 " (Valera, 2017). There is a lot of potential that can come from the Latino vote and one thing that can be done about it is to make voting more accessible by using tactics such as vote-by-mail. 


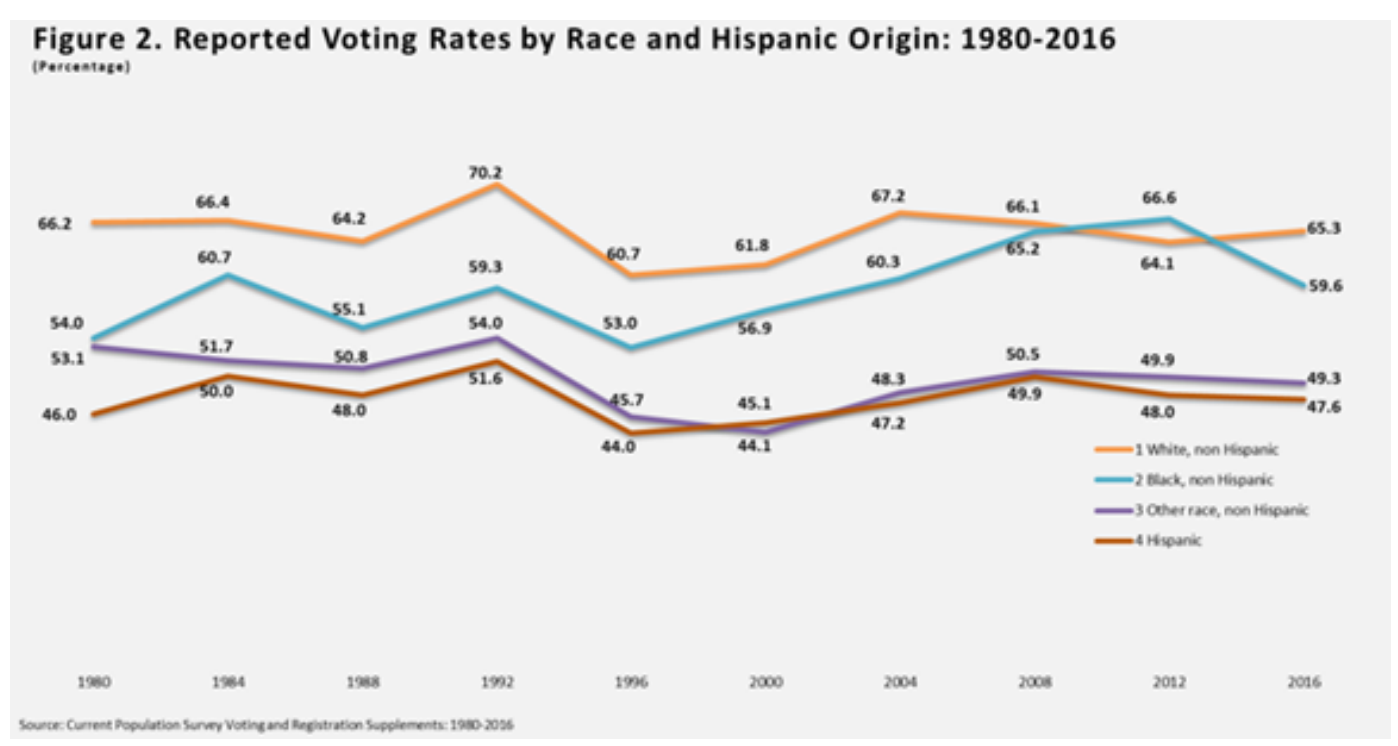

Figure 1: Since 1980, the reported rate of Latino voters has been the lowest out of all ethnic and racial groups. The highest reported voter turnout occured in 1992 and has since gone down. In the more recent years, there has been a steady decline in Latino voter turnout since 2008 (Valera, 2017).

Although obtaining the right to vote took years for many communities of color to achieve, their participation seemed welcomed. This seemed to change in 2013 after the Supreme Court case Shelby County v. Holder which opened opportunities for new avenues of voter suppression. Voter suppression is done by using a series of tactics, racial gerrymandering and voter purges. "Shelby County v. Holder ruled that... Section 4(b) of the Voting Rights Act is unconstitutional, holding that the constraints placed on certain states and federal review of states' voting procedures, known as preclearance, are outdated (Kennedy, 2021). Shortly after, numerous states enacted strict voter ID laws. For example, North Carolina "passed a law that imposed a strict photo ID requirement, significantly cut back on early voting, and reduced the window for voter registration. This is widely regarded as the most restrictive piece of voting legislation passed in recent years" (Lopez, 2014). Early assessments indicated that between 
600,000 and 800,000 registered voters in Texas lacked photo ID, over 300,000 of them being Latinos (Lopez, 2014).
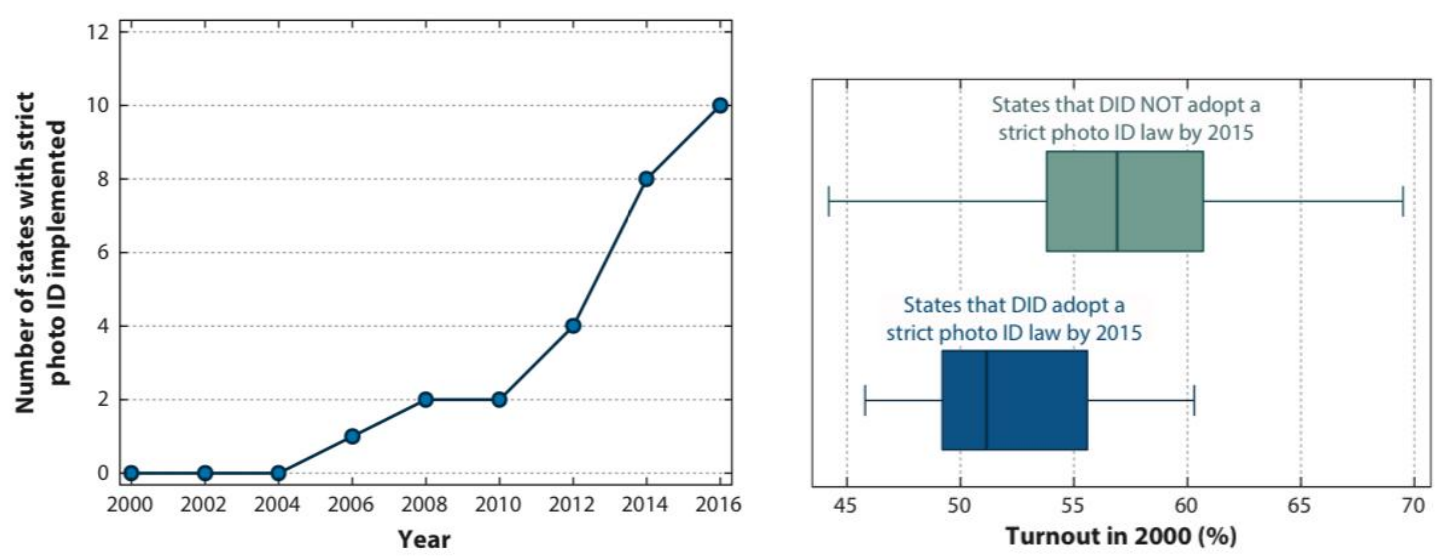

Figure 2: There is a clear increase after 2013 in the number of states with voter ID laws, which is when Shelby County v. Holder was ruled. As a result, there seems to be less voter turnout with states that adopted strict voter ID laws (Highton, 2017).

In terms of obtaining the right to vote it seems like communities of color spent decades moving forward and were unfortunately moved back after the ruling from Shelby County v. Holder. Through these ballot hoops, it seems like voter suppression is alive and affecting our democracy, but through systems such as vote-by-mail, change might be possible.

\section{Background on Vote-by-Mail}

In the state of Oregon vote-by-mail is when ballots are mailed to all registered voters weeks before an election. Voters then have time to return their ballot via mail or they can also drop it off at various drop-off locations. This can allow voters with more time to vote, drop-off ballots when they can, and do additional research on measures and candidates. Having more time to vote can enable people to make better decisions and allow people with busier schedules to have more flexibility when voting. This can be especially beneficial to communities of color and 
blue-collar workers who sometimes have multiple jobs. In addition, mail-in ballots can also come with informative pamphlets that can help voters make more informed decisions. The vote-by-mail process can be slightly different depending on the state. For example, some states have people request mail-in ballots, versus Oregon which automatically sends them to all registered voters.

In 1981, the state of Oregon passed a measure that approved vote-by-mail and according to a 2003 survey by Priscilla Southwell on voting-by-mail, nonwhites are $27.1 \%$ likely to vote more often, people who live in urban areas are $26.9 \%$ likely to vote more often, and people who earn less than $\$ 18,000$ are $35.1 \%$ more likely to vote more often. Overall, people stated that they are $29.3 \%$ more likely to vote more often, $66.6 \%$ the same, and $4.1 \%$ less (Southwell, 2004). Southwell's early findings help support the positive impact that vote-by-mail can have on voters of color. A similar trend occurred in Colorado after it implemented vote-by-mail. A 2018 study by Andrew Menger found that in 2012 they had a mean ballot cast of $65 \%$, with a mean rate of $97 \%$ in 2014 . The $32 \%$ jump came one year after Colorado implemented vote-by-mail, which is 26\% more than the jump from 2010 to 2014 (Menger, 2018). These findings by Menger and Southwell can help support the idea that some of the benefits of vote-by-mail can impact voter turnout in a positive way.

\begin{tabular}{|c|c|c|c|}
\hline & $\begin{array}{l}\text { Vote More } \\
\text { Often }\end{array}$ & $\begin{array}{l}\text { Vote About } \\
\text { the Same }\end{array}$ & $\begin{array}{c}\text { Vote Less } \\
\text { Often } \\
\end{array}$ \\
\hline $\begin{array}{l}\text { Entire Sample } \\
\text { Gender** }\end{array}$ & $29.3 \%$ & $66.6 \%$ & $4.1 \%$ \\
\hline Male & $23.3 \%$ & $72.8 \%$ & $3.9 \%$ \\
\hline Female & $32.9 \%$ & $62.7 \%$ & $4.3 \%$ \\
\hline
\end{tabular}




\begin{tabular}{|c|c|c|c|}
\hline \multicolumn{4}{|l|}{ Race $e^{n \cdot a}$} \\
\hline White & $29.6 \%$ & $66.8 \%$ & $3.6 \%$ \\
\hline Nonwhite & $27.1 \%$ & $66.1 \%$ & $6.8 \%$ \\
\hline \multicolumn{4}{|l|}{ Level of Education ${ }^{\text {n.a. }}$} \\
\hline Less than High School & $34.9 \%$ & $60.5 \%$ & $4.7 \%$ \\
\hline H.S. Diploma & $31.4 \%$ & $65.0 \%$ & $3.6 \%$ \\
\hline Some College & $31.0 \%$ & $64.3 \%$ & $4.7 \%$ \\
\hline College Degree & $28.9 \%$ & $66.4 \%$ & $4.6 \%$ \\
\hline Advanced Degree & $19.5 \%$ & $79.2 \%$ & $1.3 \%$ \\
\hline \multicolumn{4}{|l|}{ Localen } \\
\hline Urban & $26.9 \%$ & $69.2 \%$ & $3.8 \%$ \\
\hline Suburban & $34.5 \%$ & $63.2 \%$ & $2.2 \%$ \\
\hline Rural & $26.8 \%$ & $67.5 \%$ & $5.7 \%$ \\
\hline \multicolumn{4}{|l|}{ Incomenes. } \\
\hline Less than $\$ 18,000$ & $35.1 \%$ & $58.1 \%$ & $6.8 \%$ \\
\hline$\$ 18,000-\$ 25,000$ & $35.4 \%$ & $63.1 \%$ & $1.5 \%$ \\
\hline$\$ 26,000-\$ 40,000$ & $28.6 \%$ & $68.6 \%$ & $2.9 \%$ \\
\hline$\$ 41,000-\$ 70,000$ & $28.3 \%$ & $69.4 \%$ & $2.3 \%$ \\
\hline$\$ 71,000-\$ 100,000$ & $28.0 \%$ & $63.0 \%$ & $9.0 \%$ \\
\hline Over $\$ 100,000$ & $30.6 \%$ & $66.1 \%$ & $3.2 \%$ \\
\hline
\end{tabular}

Figure 3: According to the Oregon 2003 Annual Social Indicators Survey, Non-whites reported that they were $27.1 \%$ more likely to vote more frequently because of vote-by-mail (Southwell, 2004).

Vote-by-mail for presidential elections, is a system that began in Oregon around 20 years ago and has been adopted by five other states leading up to the 2016 election. Michael Hanmer and Andrew Menger both analyze the impact of vote-by-mail. Hanmer focuses on voter behavior stemming from vote-by-mail "Changing to a new system quickly, VBM or other- wise, could produce more drastic changes in behavior" (Hanmer, 2012). On the other hand, Meger looked at a more general way in which vote-by-mail reduces the undervote "we have detected a significant effect for mail balloting on ballot completion that is robust to several specifications and enhanced during presidential elections, the magnitude of this effect is very modest" (Menger, 2018). Although small, there seems to be a connection between higher voter turnout and vote-by-mail. 
Further research on the impact of vote-by-mail and voter turnout was done by Jeffrey Karp and Susan Banducci, this was done by exploring if mail voting increased participation. They found that all-mail elections usually produced higher turnout, especially in low stimulus elections. Furthermore, they noted that only mail elections were higher across the board, except for in general midterm elections (Karp and Banducci, 2000).

Although the findings from many of the previously mentioned researchers focus on states that implemented vote-by-mail years ago, the COVID-19 provided a new avenue for further research. Due to the circumstance of the 2020 election, Lynne Peeples explored the question of whether or not the rise of mail-in voting would affect the election results. She noted that mail-in ballots are more favored by people who are associated with the Democratic party. She points out that additional studies have shown an increase in voter turnout. For example, in Colorado, voter participation increased by $9.4 \%$ in 2014 . Peeples then goes on to debunk some of the negative myths about mail-in voting. One of these being the fact that fraud is rare in mail-in ballots. In addition, she points out some of the benefits that would encourage more people to use vote-by-mail. One of these being the amount of time being saved. She points out that there can be long waiting lines in polling areas due to technical glitches at the polls (Peeples, 2020). Overall, there seem to be more benefits to vote-by-mail, but the question is whether or not this same pattern is seen in voter turnout. 


\section{THE POSTAL EXPERIMENT}

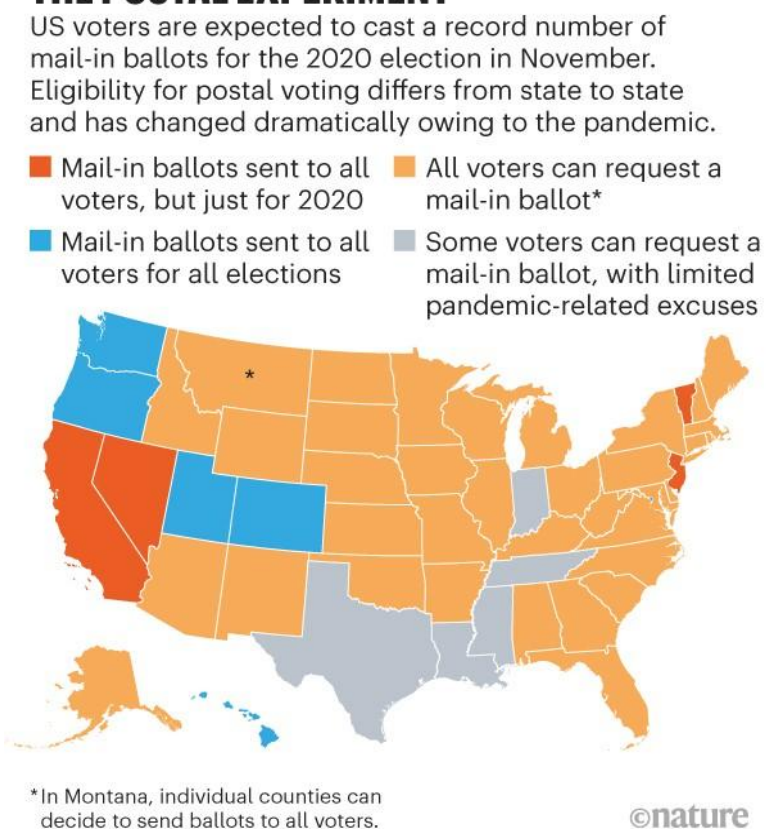

Figure 4: The different voting options given to eligible voters in the 2020 election. Most of these were implemented due to the COVID-19 pandemic (Peeples, 2020).

\section{Methodology}

In order to better understand if vote-by-mail has an impact on Lationo voter turnout, we must look at how and if voting patterns changed in states before and after the implementation of vote-by-mail. In order to do this, it is important to closely look at voter population, voter registration, and voter turnout. To better understand the possible effects of voter turnout and vote-by-mail, especially for the Latino vote the approach had to be done through variables. For this, data was collected using The Census Bureau 2016 and 2020 voting and registration data from those election years. Data was gathered from four traditionally Democratic states that had a similarity in their eligible Latino voter population, which were Illinois, Massachusetts, Oregon, 
and Washington. Two of these states were used as the control, which were Oregon and Washington since they had implemented vote-by-mail for several years. On the other hand, Illinois and Massachusetts were the new states who increased vote-by-mail usage due to the COVID-19 pandemic.

Besides all states being historically Democratic, they had Latino eligible populations in a similar range. According to The Census Bureau data, Oregon had a Latino population of 18 years and older of $11.6 \%$ in 2016 and in 2020 it was $8.4 \%$. Washington's Latino voter population was $11.7 \%$ in 2016 and in 2020 it was $11.4 \%$. On the other hand, Illinois had a Latino population of 18 years and older of $15.3 \%$ in 2016 and $14.7 \%$ in 2020. Massachusetts' Latino voter population was $9.3 \%$ in 2016 and $11.5 \%$ in 2020 . The data was collected as reported voting and registration by sex, race, and Hispanic origin for states under The Census data. Although the data gathered under the voting method section is not specific enough in regards to ethnicity and race, it is important to note that after the 2020 election The Census Bureau added a method of voting to its data, meaning that vote-by-mail had a greater impact on voter turnout than ever before.

\section{Population of Latino Eligible Voters}

2016: Eligible Latino Voters

2020: Eligible Latino Voters

20

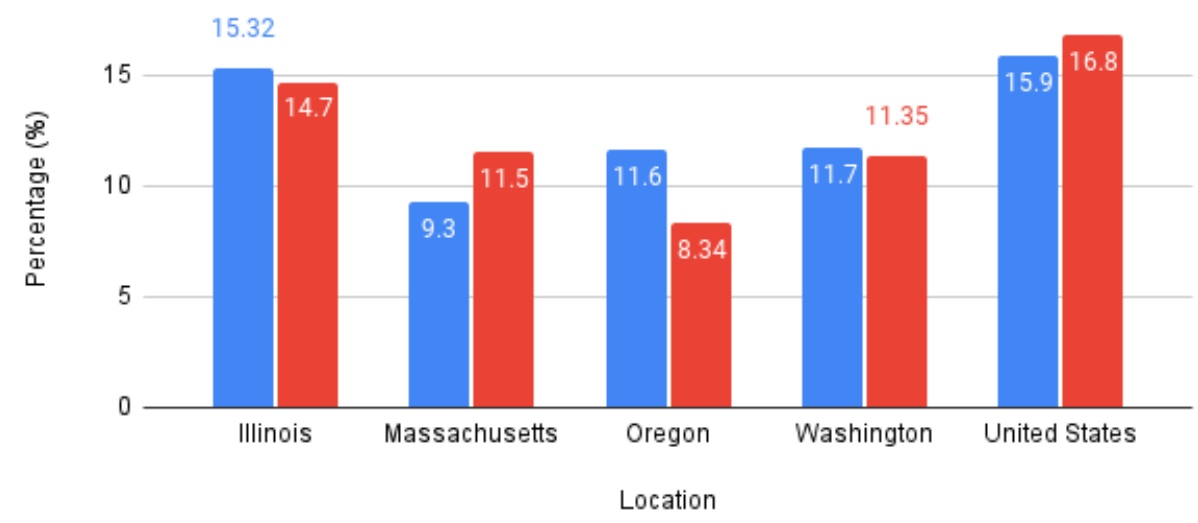


Figure 5: 2016 and 2020 Latino eligible voter population for recorded states along with the United States.

Source: Voting and Registration in the Election November 2016. The

Census Bureau.

\section{Data and Findings}

We examined data comparing the 2016 and 2020 election with a focus on three things which were Latino voter population, Latino registration, and Latino voter turnout. After analyzing the data between both elections and the states, we were able to find interesting data. For example, when it came to voter registration there was an increase in Latino registration of 5.6\% from 2016 to 2020 in Oregon. Washington had a decrease in Latino voter registration of 1\%. Illinois had a drop in Latino voter registration of 5.1\%. From 2016 to 2020 Massachusetts had a Latino voter registration increase of $2.8 \%$ (see figure 6 ).

\section{Registered Latino Voters}

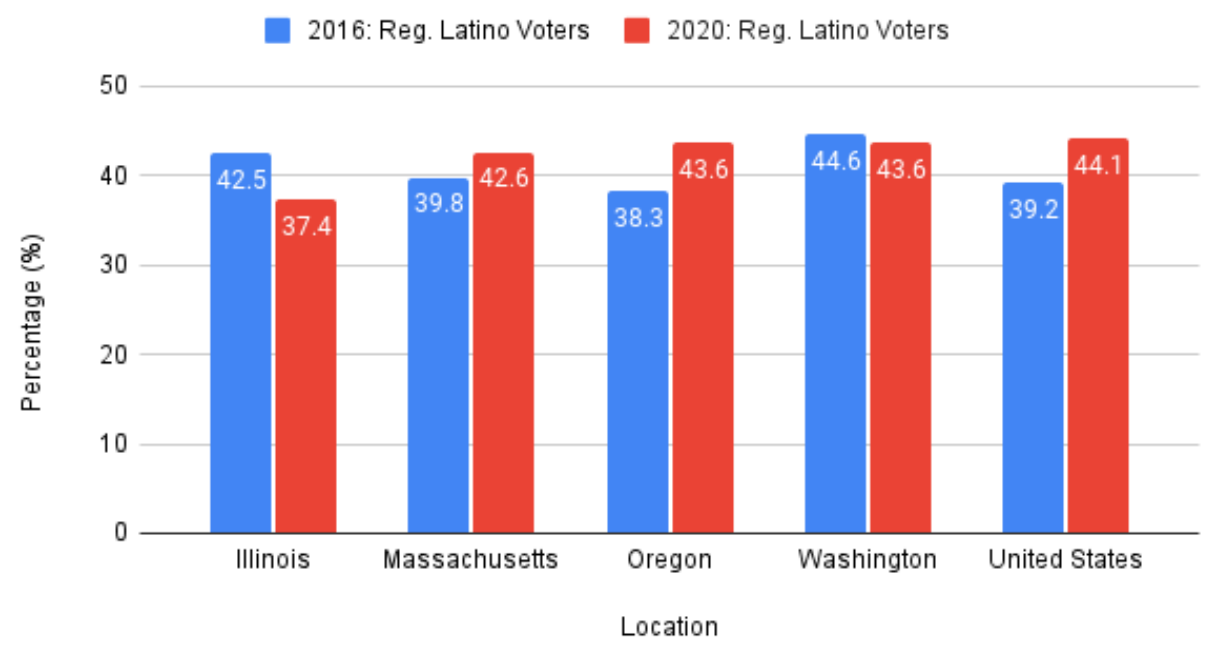

Figure 6: Registered Latino voters from 2016 to 2020

for recorded states along with the United States.

Source: Voting and Registration in the Election November 2020. The Census Bureau. 
Although Latino registration trends are important within themselves, it's imperative that they are compared and looked at next to Latino voter turnout. Voter turnout helps us better understand how many voters are exercising their right to vote. The data found that Oregon had a Latino voter turnout that decreased 3\% from 2016 to 2020. On the other hand, in Washington there was an increase of $6.5 \%$ in Latino voter turnout. From 2016 to 2020 Illinois had a decrease in Latino voter turnout of $2.4 \%$. On the other hand, Massachusetts had an increase in Latino voter turnout of $6.1 \%$ (see figure 7). When looking at the data individually and comparing voter registration to turnout, it doesn't seem that VBM has had a positive effect, however, this can change when looking at it collectively. Latino voter registration at a national level increased by $4.9 \%$ and voter turnout grew $6.1 \%$. Based on voting method data, we can assume that a large number of these votes were done via mail.

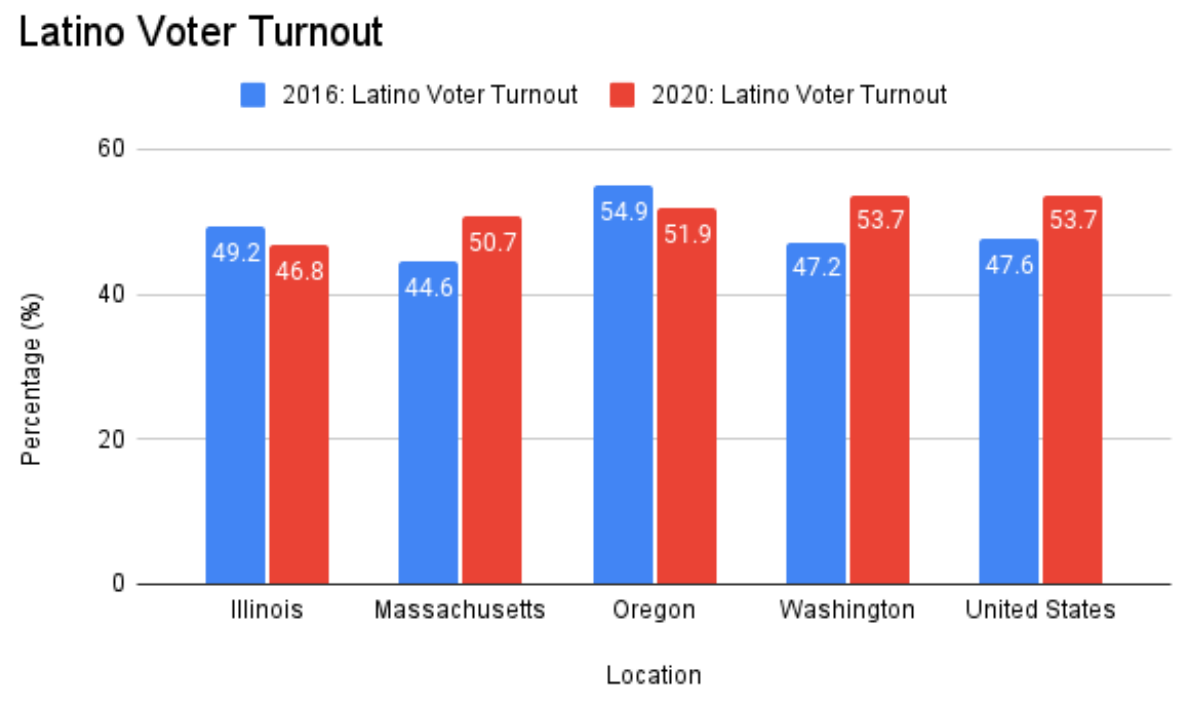

Figure 7: Latino voter turnout from 2016 to 2020

for recorded states along with the United States. Source: Voting and Registration in the Election November 2020. The Census Bureau. 
In order to see the larger effects of how vote-by-mail affects voter turnout, it is important to look at the data from an individual and holistic perspective. When looking at all states collectively, the results show an overall increase in voter turnout from Latinos. The average Latino voter registration for the control states rose by $2.3 \%$ and their turnout was increased by $1.3 \%$. When it came to the new states, average voter registration between the two declined $2.3 \%$ but voter turnout increased $1.85 \%$. This means that when looking at all four states as a whole, voter registration remained the same, while Latino voter turnout increased $1.6 \%$. When looking at the data at a national level, the eligible Latino voter population increased by $1.1 \%$ from 2016 to 2020. Overall, when looking at the data across all four states and even at the national level, there is an increase in Latino voter turnout from 2016 to 2020, which in part can be attributed to the implementation of vote-by-mail.

Before the 2020 election, only a handful of states had vote-in-mail, which is why the collection of voting methods data is not collected by the census before 2020 . Due to the pandemic, vote-by-mail was implemented by numerous states and this led to the collection of that data. As seen in figure seven, $46.7 \%$ of votes in the United States were done via mail, while the other $52.3 \%$ were done in person (see figure 8 ). With this, we can assume that this pattern remains through all voters, meaning that at least $46.7 \%$ of Latinos voted by mail.

\begin{tabular}{|l|l|l|l|}
\hline $\begin{array}{l}\text { 2020: Voting } \\
\text { Method }\end{array}$ & & & \\
\hline State & In-Person \% & By Mail \% & N/A \% \\
\hline United States & & & \\
\hline
\end{tabular}

Figure 8: Data on method of voting by selected characteristics. Source: Voting and Registration in the Election November 2020. The Census Bureau. 


\section{Limitations}

At the start of the writing process for this paper, I had the idea that the government collected more voting data, but I was wrong. Initially, the four states that the paper would focus on were Oregon, Massachusetts, Rhode Island, and Washington. Due to the small size of Rhode Island voting data from The Census Bureau was not available. Although this did not seem like an issue, it quickly became one when the state website did not provide race and ethnic-based voting data. The only data available was that of voting trends in counties and the state as a whole, which then led me to look at Illinois as the additional state.

It is important to recognize that before the COVID-19 pandemic, there was no collection of voting methods by The Census Bureau, which means that these voting trends can only be looked at on a smaller scale. Even with the new implementation and collection of voting method data, there is still a lack of specificity. It would be helpful to be able to look at voting data and trends more closely, especially when it comes to topics about race. Even if the voting method data was not collected before 2020, it would have been helpful to see how these voting methods are shown through race and ethnic background. Along with this, the political climate during the 2020 election had a great influence on voter turnout, but it is hard to tell how and if the political climate was the sole reason why some citizens voted and if so how much that influenced the outcome. Despite these limitations there is a significant positive association that can be drawn between VBM and Latino voter turnout and which is that after the large-scale implementation of VBM Latino turnout is no longer on the steady decline it had been in since 2008 .

\section{Conclusion}

The COVID-19 pandemic opened a new avenue for research and had it not been for it, maybe this would have taken years to achieve. Systems of voter suppression have been embedded in the American voting system and it is time that the voting gap is closed. From only 
allowing white and wealthy men to vote early on in our history, to finally giving people of color the right to vote in the 20 th century, the right to vote will continue until voting becomes accessible. There is this idea that everyone's vote counts, but this is not the case when a series of anti-voting tactics are implemented at the state and local levels. The rise of such tactics was being prevented but this is no longer the case after Shelby County v. Holder. More needs to be done at the federal level so that states do not control voting so much that they keep eligible voters out.

Vote-by-mail might not be the sole solution, but it shows promise and if done correctly the voter turnout gap can begin to decrease. With the support of vote-by-mail at a national level, many states saw an increase in its use. For example, Rhode Island saw an increase in vote-by-mail usage of $24 \%$ and an overall voter turnout in the general election of $64.1 \%$ which was the highest since 1970 (2021). Furthermore, mail-in ballots in Massachusetts accounted for $42 \%$ of the voting method, and $93 \%$ of voters who requested ballots returned them (Kashinsky, 2020). A similar trend occurred in Illinois where the total voter turnout was $72.9 \%$, which was the highest since 1992 with one-third of these votes coming from mail-in ballots (Hinton, 2020). Overall, the use of mail-in-ballots when available is the method of voting for a large number of voters.

When it comes to Latino Voter turnout, there is more that can be done within the community to promote voting culture. There is no clear direct correlation between voter turnout and voting by mail because the data that would create this connection does not exist. However, it is important to note that after vote-by-mail was implemented and supported at a national level, Latino voter turnout increased by $6.1 \%$ and is no longer in the steady decline it was since the 
2008 election. As a community, it behooves us to encourage voting within the youth and all eligible voters so that the nation can truly encompass the democracy it was meant to be. 


\section{Works Cited}

Berkman, Seth. "States That Had the Highest 2020 Voter Turnout." Stacker, 6 January 2021, https://stacker.com/stories/6202/states-had-highest-2020-voter-turnout.

Bureau, U. (2021, April 29). 2020 presidential election voting \& Registration tables now available. Retrieved May 13, 2021, from https://www.census.gov/newsroom/press-releases/2021/2020-presidential-election-voting -and-registration-tables-now-available.html

Combs, Barbara Harris. "Black (and Brown) Bodies Out of Place: Towards a Theoretical Understanding of Systematic Voter Suppression in the United States." Critical Sociology, vol. 42, no. 4-5, 2016, pp. 535-549.

Fraga, Luis Ricardo. "The Origins of the 1975 Expansion of the Voting Rights Act: Linking Language, Race, and Political Influence." US Latina \& Latino Oral History Journal 1 (2017): 7-28.

Hanmer, Michael J, and Traugott, Michael W. "The Impact of Voting by Mail on Voter Behavior.” American Politics Research, vol. 32, no. 4, 2016, pp. 375-405.

Highton, Benjamin, and Burris, Arthur L. "New Perspectives on Latino Voter Turnout in the United States.” American Politics Research, vol. 30, no. 3, 2016, pp. 285-306.

Highton, Benjamin. "Voter Identification Laws and Turnout in the United States." Annual Review of Political Science, vol. 20, no. 1, 2017, pp. 149-167.

Hinton, Rachel. "Over 6 million Illinois residents cast ballots in 2020 election.” Chicago Sun Times, 4 December 2020, https://chicago.suntimes.com/elections/2020/12/4/22153939/illinois-presidential-electionturnout-voting.

Jeffrey A. Karp, and Susan A. Banducci. “Going Postal: How All-Mail Elections Influence Turnout.” Political Behavior, vol. 22, no. 3, 2000, pp. 223-239.

Kashinsky, Lisa. "Mail-in ballots made up 42\% of Massachusetts votes cast in November election." Boston Herald, 20 November 2020, https://www.bostonherald.com/2020/11/20/mail-in-ballots-made-up-42-of-massachusettsvotes-cast-in-november-election/ 
Kennedy, Lesley. "Voting Rights Milestones in America: A Timeline.” History, 2021, https://www.history.com/news/voting-rights-timeline. Accessed 19 April 2021.

Lopez, Tomas. "Shelby County’: One Year Later." Brennan Center for Justice (2014).

Menger, Andrew, et al. "Reducing the Undervote With Vote by Mail.” American Politics Research, vol. 46, no. 6, 2018, pp. 1039-1064.

Mills, Kay. "Black America's Long Fight Against Vote Dilution. Los Angeles Times, Jun 17, 1990, pp. 2.

Peeples, Lynne. "COVID and the US Election: Will the Rise of Mail-in Voting Affect the Result?” Nature (London), 2020, pp. Nature (London), 2020-10-23.

Person. (2021, May 04). Voter turnout in RI. Retrieved May 13, 2021, from https://storymaps.arcgis.com/stories/6645c173c1f343e0a2411034e4594402

Shelby County, Ala. v. Holder, 133 S. Ct. 2612, 570 U.S. 529, 186 L. Ed. 2d 651 (2013).

Southwell, Priscilla L. "Five Years Later: A Re-Assessment of Oregon's Vote by Mail Electoral Process." Political Science and Politics, vol. 37, no. 1, 2004, pp. 89-93.

Varela, Julio R. "New Census Data Says 2016 National Latino Voter Turnout Rate Did Not Increase." Latino USA, 15 May 2017

Wesley, Charles H. "Racism and Voting.” Negro History Bulletin, vol. 35, no. 5, 1972, p. 100. 